\title{
Reliable Treatment of Petroleum Processing Wastewater Using Dissolved Air Flotation in Combination with Advanced Oxidation Process
}

\author{
M.H. El-Awady, I. Abdelfattah* and A. Abo El-Magd ${ }^{\#}$ \\ Water Pollution Research Department, National Research \\ Centre, 33 EL Bohouth St., P.O. 12622, Dokki, Giza and ${ }^{\#}$ Civil \\ Engineering Department, Faculty of Engineering, Shoubra, \\ Banha University, Egypt.
}

\begin{abstract}
IL refinery processes mill wastewater originating from highly contaminated outlet with persistent organic pollutants is the main polluted part in end-of pipe of oil industry. This study has been carried out to investigate the application reliability of diffused air flotation (DAF) and advanced oxidation processes (AOPs) with particularly Fenton reaction for the treatment of this type of wastewater. Two sequenced wastewater samples were collected from Petroleum Refinery Company located at a coastal city, Egypt. The first was from the API-oil separation discharging point where it has been treated by DAF- unit, while the second was collected from Naphtha section outlet that highly contaminated with phenolic compounds. It has been treated with Fenton process in batch laboratory-scale. Results showed that at the optimal operating conditions, DAF-experiment fulfilled appropriate removal of total oil and grease up to $98 \%$, while its efficiency in removing both COD and TSS was exceeding $96 \%$ and $92 \%$, respectively. On the other hand, samples collected from Naphtha department outlet that subjected to Fenton reaction showed remarkable destruction of phenolic contents up to $99.9 \%$; and $88 \%$ for COD, at their optimal operating conditions, respectively.
\end{abstract}

Keywords: Refinery wastewaters, Treatment, DAF-unit, Fenton reaction and Phenols.

Wastewater originating from Oil Refinery Processes Mill (ORPM) was highly contaminated with hydrocarbons which represented the main source of pollution in this industry. ORPM is discharging to the sea large quantities of partially treated wastewater that characterized by high values of $\mathrm{pH}$, Chemical Oxygen Demand (COD), Total Suspended Solids (TSS), Oil and Grease (O \& G), respectively $^{(1)}$. Also, Coates ${ }^{(2)}$ and Syllos et al. ${ }^{(3)}$ reported that the generated wastewater in oil industry contained several organic compounds, such as Benzene, Toluene, Ethylbenzene, and Xylenes (BTEX), its disposal to the sea has been regulated by National Law 4/1994. ORPM wastewater is considered as dangerous compounds to the environment because of their migration abilities, both in aquatic and land environments, and their acute and chronic toxicities. The significant amount of refinery wastewater has to be treated and processed before

*Corresponding author : iabdelhafiz@yahoo.com,

Tel: 0020-12-74999938, Fax 0020-2-374840077 
their discharge into water streams. The refinery wastewater treatment plants employ physicochemical processes including American Petroleum Institute (API) separator as a primary treatment and dissolved air flotation technique as a secondary treatment, to achieve effluents of satisfactory oil content. Flotation is investigated as a post-treatment process for the removal of emulsified hydrocarbons and satisfactory results were obtained ${ }^{(4)}$. On the other hand, Tony et al. ${ }^{(5)}$ showed that conventional treatment processes have difficulty in fully removing emulsified oil or small oil droplets. Diffused Air Flotation (DAF) process exhibited remarkable results in removing floatable and suspended materials and it was an effective method to separate oil from aqueous dispersion, chemically treated wastewater, and refinery wastewater ${ }^{(6,7)}$. According to Metcalf \& Eddy, Inc. ${ }^{(8)}$, the air to solids ratio (A/S) was considered one of the most important parameter in the design of air flotation system. However, different types of influent characteristics generated different ranges of $\mathrm{A} / \mathrm{S}$ ratios. The optimal A/S range for a particular feed must be determined experimentally. The corresponding equation (1) for a system with only pressurized recycle is:

$$
\overline{\mathrm{S}}=\frac{1.3 \mathrm{~S}_{\mathrm{a}}(f \rho-1) \mathrm{R}}{\mathrm{S}_{\mathrm{a}} \mathrm{Q}}
$$

where $\mathrm{A} / \mathrm{S}$ is the air to solids ratio in $\mathrm{ml}$ air to $\mathrm{mg}$ solids; $\mathrm{S}_{\mathrm{a}}$ : the air solubility $(\mathrm{ml} / \mathrm{L}) ; f$ : the fraction air dissolved at pressure $\mathrm{P}$, usually 0.5 ; $\mathrm{P}$ : pressure, atm. =

$\frac{p+101.35}{101.35}$ (SI units)

gage pressure, $\mathrm{KPa}$; Sa: influent suspended solids, $(\mathrm{mg} / \mathrm{L})$; R: the pressurized recycle; Q: the influent flow rate; The factor of 1.3 is the weight in milligrams of $1 \mathrm{ml}$ of air and the term (-1) accounts for the system operating at atmospheric conditions (gage pressure). The dry density of dry air is $1.3 \mathrm{mg} / \mathrm{ml}$ at $1 \mathrm{~atm}$ and $0{ }^{\circ} \mathrm{C}$.

Fenton reaction ${ }^{(9)}$, equation (2) is one effective process of Advanced Oxidation Processes (AOPs); where the iron-salt-dependent decomposition of hydrogen peroxide, generating the highly reactive hydroxyl radical $\left(\mathrm{HO}^{-}\right)$. Fenton's reagent can be used to destroy organic compounds utilizing the $\mathrm{HO}^{-}$(10). Haber and Weiss suggested the $\mathrm{Fe}^{2+}$ regeneration by in which a superoxide radical as indicated in equations $(3 \text { and } 4)^{(11)}$.

$$
\begin{aligned}
& \mathrm{Fe}^{2+}+\mathrm{H}_{2} \mathrm{O}_{2}+\mathrm{Fe}^{3+}+\mathrm{HO}^{-}+\mathrm{HO}^{-} \\
& \mathrm{OH}+\mathrm{H}_{2} \mathrm{O}_{2} \rightarrow \mathrm{H}^{+}+\mathrm{H}_{2} \mathrm{O}+00^{-} \\
& \mathrm{Fe}^{3+}+\mathrm{OO}^{-} \rightarrow \mathrm{Fe}^{2+}+\mathrm{O}_{2} \uparrow
\end{aligned}
$$

AOPs provided a high degradation capacity for petroleum wastewater that was extremely important in the oil industry, since they allowed the reuse of

Egypt. J. Chem. 58, No.6 (2015) 
water. After an extensive study, El-Awady et al., concluded that the addition of $\mathrm{H}_{2} \mathrm{O}_{2}$ in photocatalytic reaction achieved detectable degradation of dissolved organic pollutants in wastewater ${ }^{(12)}$. It fulfilled efficient removal of contaminants that persisted and were hard to remove using conventional methods.

The case study under investigation was representing a petroleum refinery company located at a coastal city, Egypt. Its hourly discharging was $700 \mathrm{~m}^{3}$ of insufficient treated industrial wastewater; mixed with $9000 \mathrm{~m}^{3}$ cooling water with total wastewater exceeding $9700 \mathrm{~m}^{3} / \mathrm{h}$ to the sea. The existing treatment system was based on the collection of Industrial Wastewater (IWW) from production lines. Their discharges were $12.5 \mathrm{~m}^{3} / \mathrm{h}$ from Naphtha and $687.5 \mathrm{~m}^{3} / \mathrm{h}$ from API oil separator, respectively. The total IWW then passed to Skim Basin (SB) where the $9000 \mathrm{~m}^{3} / \mathrm{h}$ cooling water was thoroughly mixed with the industrial wastewater discharged from Naphtha section division and API oil separator. The last section represented the main source of organic pollutants, with high phenolic content, high alkalinity and COD exceeding the trigger levels in Law 4/1994 regulating the discharge of water onto the sea. DAF was selected to remove suspended solids, free and emulsified oils, while Fenton reaction was chosen to destruct the high organic load in Naphtha waste.

\section{Materials and Methods}

\section{Materials}

Freshly prepared $1.0 \mathrm{~N}$ heptahydrated ferrous sulphate $\left(\mathrm{FeSO}_{4} \cdot 7 \mathrm{H}_{2} \mathrm{O}\right)$, hydrogen peroxide $30 \%\left(\mathrm{H}_{2} \mathrm{O}_{2}\right)$, dodecahydrated potassium aluminum sulfate $\mathrm{KAl}\left(\mathrm{SO}_{4}\right)_{2} .12 \mathrm{H}_{2} \mathrm{O}$ utilized in the DAF process for enhancement of oil separation and removal, $50 \%$ sodium hydroxide and $30 \%$ sulphuric acid were prepared daily for $\mathrm{pH}$ adjustment and naphtha wastewater outlet and API-oil separation unit samples.

\section{Methods and utilities}

A solution of $\mathrm{Fe}^{2+}$ was prepared from ferrous sulfate heptahydrate $\left(\mathrm{FeSO}_{4} \cdot 7 \mathrm{H}_{2} \mathrm{O}\right)$ and hydrogen peroxide $(30 \%$, by weight $)$ was used in the experiments as the Fenton's reagent for hydroxyl radical generation. Sulfuric acid and sodium hydroxide were used to adjust the $\mathrm{pH}$ to the desired values.

\section{Jar test experiment}

Coagulation tests have been performed according to Jar-test method as shown in Fig.1, using a standard Flocculation Stuart Scientific, equipped with two mixing posts. This step was done by flash mixing step (200 rpm) for $2 \mathrm{~min}$, while flocculation step was done for $10 \mathrm{~min}$, at (28-30) rpm, followed by a settling time of $30 \mathrm{~min}$. Tests have been performed in 1 liter cylindrical beakers, at room temperature $(20 \pm 1){ }^{\circ} \mathrm{C}$, using raw inlet wastewaters. 


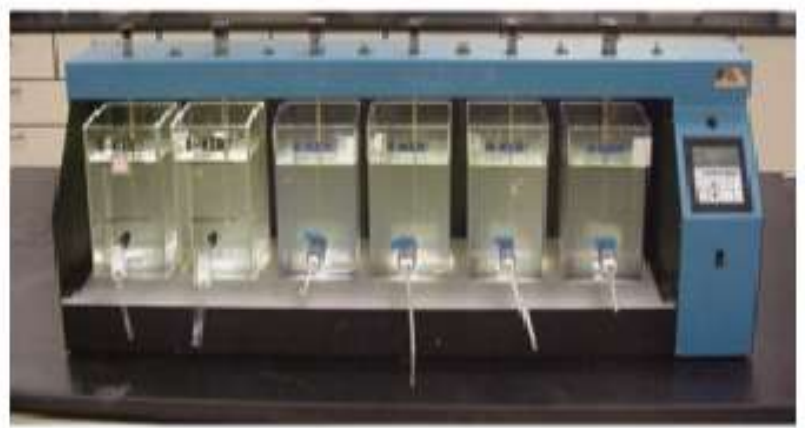

Fig.1. Standard Jar test apparatus.

Chemical coagulation/flocculation using alum solution in-combination with DAF process was performed to API outlet sample. DAF unit (Fig. 2) was designed based on Jar-test criteria to achieve the optimum operating conditions. The floatation unit (FU) was made from calibrated Plexiglas column, with $85 \mathrm{~cm}$ length and $5 \mathrm{~cm}$ diameter. The pressurized air/water mixture was released from the retention tank to the floatation cell through a pressure reducing valve (PRV) at the tank bottom. Air /water in the pressure tank were saturated with air at a pressure of $4 \mathrm{~kg} / \mathrm{cm}^{2}$. The dissolved air was gradually released to the FU.

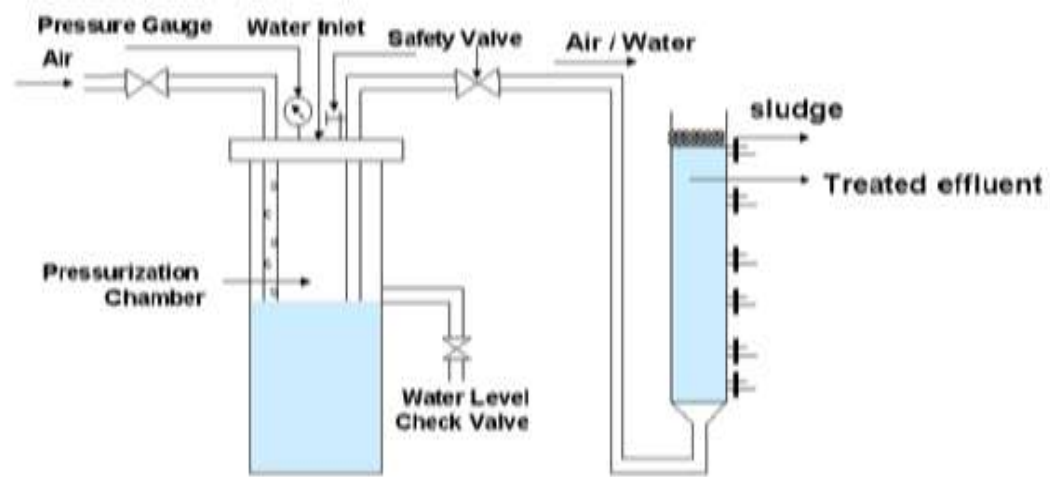

Fig.2. Schematic diagram of DAF Lab unit.

To determine the optimal $\mathrm{Fe}^{2+}, \mathrm{H}_{2} \mathrm{O}_{2}$ dosages, the optimal $\mathrm{pH}$ and reaction time, in addition to achieve maximal removal of chemical oxygen demand (COD) and phenol; Fenton reaction has been carried out and performed according to Jar Test (Fig. 2). Hydrated ferrous sulphate $\left(\mathrm{FeSO}_{4} \cdot 7 \mathrm{H}_{2} \mathrm{O}\right)$ as well as $30 \%$ hydrogen peroxide $\left(\mathrm{H}_{2} \mathrm{O}_{2}\right)$ were used as components of Fenton reaction.

Six Jars of naphtha wastewater and Fenton reagents were carefully mixed at $50 \mathrm{rpm}$ for $10 \mathrm{~min}$.

Egypt. J. Chem. 58, No.6 (2015) 
$\mathrm{FeSO}_{4} \& \mathrm{H}_{2} \mathrm{O}_{2}$ doses, reaction time, and other optimal operating conditions were calculated. Because Fenton reaction is exothermic; the reactors were cooled during chemical addition. Freshly prepared sodium hydroxide $(50 \%)$ and $(30 \%)$ sulphuric acid were added to adjust the $\mathrm{pH}$-value of the treated effluent.

\section{Operational principals}

Coagulants were mixed with wastewater, pressurized air was introduced, released as micro-bubbles (30-100) microns, Oil droplets were rapidly migrated to the top, sludge as floated blanket was skimmed and clean treated wastewater was collected from outlet.

To determine the optimal coagulant dose and Fenton's operating conditions; a flotation column and cooled Jar test experiment were used, respectively. Alum was used as coagulant during flotation experiments, while $\mathrm{Fe}^{2+}$ and $\mathrm{H}_{2} \mathrm{O}_{2}$ reagents were used in the experimental work of Fenton reaction. The optimal $\mathrm{pH}$ and reaction time were calculated to achieve maximal removal of chemical oxygen demand (COD) and phenol. Both flotation and Fenton reaction experiments were carried out in accordance with Syllos et al. ${ }^{(3)}$. All measured parameters of raw and treated wastewaters have been analyzed according to procedures given in the American standard methods ${ }^{(13)}$.

\section{Results and Discussion}

Characterization of raw wastewaters

Table 1 shows the main physico-chemical characteristics of the raw wastewaters outlets from: Naphtha Dept.; oil separator; cooling water of API (American Petroleum Institute) and final tank, respectively.

TABLE 1. Physico-chemical analysis of raw wastewaters from different outlets.

\begin{tabular}{|c|c|c|c|c|c|c|}
\hline \multirow[b]{2}{*}{ Parameters } & \multirow[b]{2}{*}{ Unit } & \multicolumn{4}{|c|}{ Result * } & \multirow[b]{2}{*}{$\begin{array}{c}\text { Law 4/ } \\
1994 * *\end{array}$} \\
\hline & & $\begin{array}{c}\text { Naphtha } \\
\text { Dept. }\end{array}$ & $\begin{array}{c}\text { Oil } \\
\text { Separator }\end{array}$ & $\begin{array}{c}\text { Cooling } \\
\text { water }\end{array}$ & Final Tank & \\
\hline $\mathrm{pH}$ & -- & 13.6 & 7.5 & 7.5 & 6.5 & $6-9$ \\
\hline COD & $\mathrm{mgO}_{2} / \mathrm{L}$ & 8200 & 1384 & 1326 & 4360 & 100 \\
\hline $\mathrm{BOD}_{5}$ & $\mathrm{mgO}_{2} / \mathrm{L}$ & 3286 & 554 & 523 & $\mathrm{NI}$ & 60 \\
\hline TSS & $\mathrm{mg} / \mathrm{L}$ & 438 & 3314 & 22 & 68 & 60 \\
\hline TDS & $\mathrm{mg} / \mathrm{L}$ & 55600 & 65300 & 56130 & $\mathrm{NI}$ & $==$ \\
\hline $\mathrm{H}_{2} \mathrm{~S}$ & $\mathrm{mg} / \mathrm{L}$ & N.D. & ND & N.D. & N.D. & 1 \\
\hline Phosphate & $\mathrm{mg} / \mathrm{L}$ & 0.4 & 0.18 & N.D. & $\mathrm{NI}$ & $==$ \\
\hline Chlorides & $\mathrm{mg} / \mathrm{L}$ & 420 & 52000 & 51000 & $\mathrm{NI}$ & $==$ \\
\hline Phenol & $\mathrm{mg} / \mathrm{L}$ & 160 & 0.2 & 2.0 & 0.12 & 0.01 \\
\hline TKN & $\mathrm{mg} / \mathrm{L}$ & 17 & 106.5 & $\mathrm{NI}$ & $\mathrm{NI}$ & 10 \\
\hline $\mathrm{O} \& \mathrm{G}$ & $\mathrm{mg} / \mathrm{L}$ & $\mathrm{NI}$ & 707 & 12 & 15 & 10 \\
\hline $\begin{array}{l}\text { Discharging- } \\
\text { Capacity }\end{array}$ & $\mathrm{m}^{3} / \mathrm{h}$ & 12.5 & 687.5 & 9000 & 9700 & $==$ \\
\hline
\end{tabular}

* Results of three successful replicates. NI: Not identified, ND: Not detected.

** Trigger levels of Law 4/1994; regulating the limits of discharging wastewater to the sea. 
Due to the highly organic content of the Naphtha Department outlet (160 mg phenol/1 and $8200 \mathrm{mg} \mathrm{O} / \mathrm{L}$ ), with about $7.0 \%$ from the total discharging capacity, it was suggested to be segregated and treated separately using Fenton reaction. Although Fenton reaction was costly, but it saved lots of chemicals and infrastructures, running costs if compared with an overall treatment system of the total discharging wastewater.

On the other hand, DAF unit will be effectively for the removal of all floated as well as oily matters from the final wastewater. After carrying out this treatment method, the final treated wastewater from all separate sectors will meet the trigger values of discharging the treated wastewater onto the sea and to fulfill the requirements of the Environmental Egyptian Law 4 /1994.

Detection of the optimum removal of Oil, TSS \& COD from API outlet using DAF unit

The optimum operating conditions of the treatment was carried out according to coagulation/ flocculation followed by dissolved floatation process DAF. Alum was chosen as relevant coagulant because the produced sludge was fluffy to be floated and skimmed. Its optimum detected dose was of $\mathrm{Al}^{3+}$ at the original $\mathrm{pH}$ 6.5-7.0 of the wastewater was measured. Table 2 reveals the average of three replicates of raw and treated samples including the mean removal efficiencies.

TABLE 2. Physico-chemical analysis of floating cell influent, and effluent .

\begin{tabular}{|l|c|c|c|}
\hline \multicolumn{1}{|c|}{ Parameter $(\mathbf{m g} / \mathbf{L})$} & Raw IWW & Treated IWW & $\boldsymbol{\%} \mathbf{R}$ \\
\hline COD & 200 & 8 & $96 \%$ \\
\hline TSS & 1013 & 23 & 97.7 \\
\hline Oil \& Grease & 707 & 9 & 98.7 \\
\hline
\end{tabular}

Design of DAF unit for the oily wastewater

A typical schematic and the diagram of DAF layout of the designed DAF systems are shown in Fig. $3 \& 4$. The experimental results showed the optimum operating conditions as: alum dose $75 \mathrm{mg} \mathrm{Al}^{3+} / \mathrm{L}$, surface loading rate 70 liter of wastewater/ square meter of surface area per minutes and $\mathrm{A} / \mathrm{S}$ of $0.008 \mathrm{ml} / \mathrm{L}$, respectively. Reference to equation (1), the calculated recycled flow was $16500 \mathrm{~m}^{3} / \mathrm{h}$. 


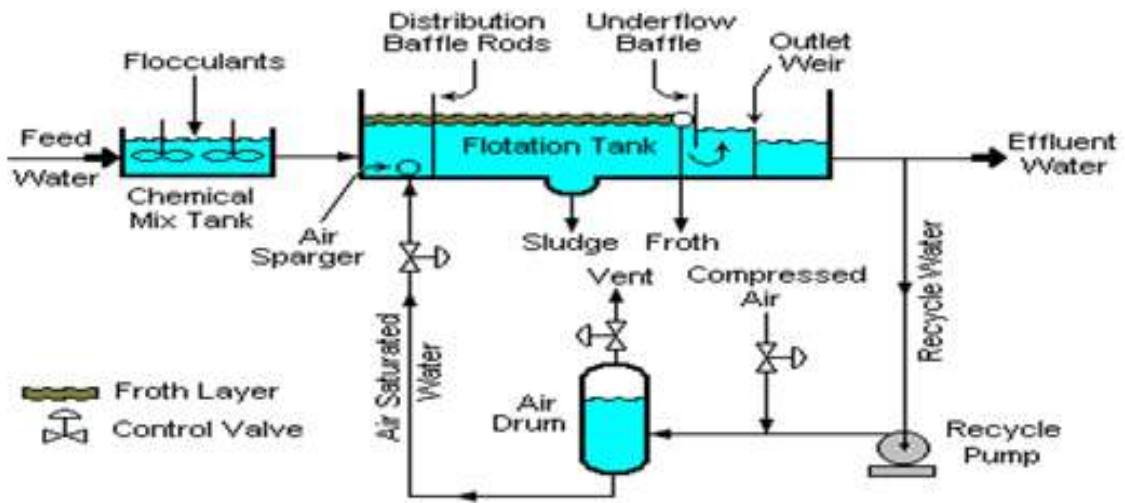

Fig. 3. Schematic diagram of dissolved-air flotation system.

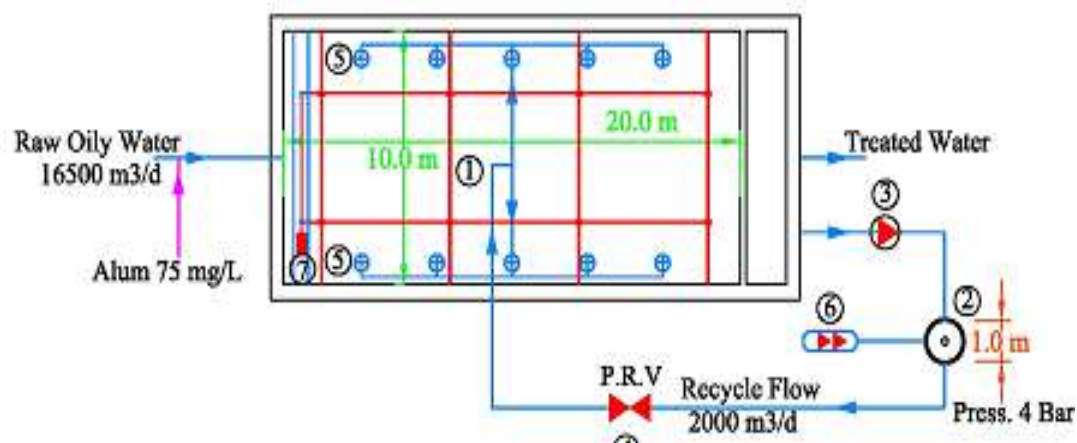

(4)

Le gends: 1- Floatation tank, depth=2 $\mathrm{m} ; 2$ - Water-air contact Tank, depti=1 m; 3- Recycling pume,

4- Pressure relief valve; 5-Air Spargers; 6-Air compressor; 7- Skimmer [Scale: 1:200]

Fig. 4. Layout plan for designed dissolved-air flotation system.

In the DAF treatment process, a compressed air was injected into a pressure vessel of diameter $1.0 \mathrm{~m}$ and height of $1.2 \mathrm{~m}$ for one vessel or $0.8 \mathrm{~m}$ diameter and $1.0 \mathrm{~m}$ height for two vessels, containing part of the recycled treated wastewater of a $2000 \mathrm{~m}^{3} / \mathrm{d}$ at 4 Bars. Sufficient time was being allowed in this vessel for air saturation for about $3 \mathrm{~min}$. Air compressor was used efficiently to mix air with the purified recycled wastewater. The recycled flow was released toward the base of the floatation tank via a pressure release valve (P.R.V), allowing the air to come out through the wastewater matrix and creating fine homogenous air carpet. The floatation tank was designed for influent and recycled flow with 30 min retention time. To fulfill maximum removal efficiency, its design dimensions 
were designed as: $10.0 \mathrm{~m}$ width, $20.0 \mathrm{~m}$ length and $2 \mathrm{~m}$ height. For one floatation tank or $7.0 \mathrm{~m}$ width, $14.0 \mathrm{~m}$ length and $2.0 \mathrm{~m}$ height for two floatation tanks.

The obtained results revealed that DAF process exhibited good results in removing floatable materials as well as suspended solids with remarkable efficiency that exceeded $95 \%$. Obtained results matched with that obtained by ElAwady ${ }^{(6)}$. Moreover, Abdel Megid et al. ${ }^{(4)}$ concluded that different responses to the coagulant treatment were observed within the tested samples, Ferrous sulphate at $\mathrm{pH}=10$ removed $67 \%$ oil, Alum at $\mathrm{pH}=10$ removed $73 \%$ oil, Ferric chloride at $\mathrm{pH}=8$ removed $74 \%$ oil, other combinations with manufactured chemicals removed up to $87 \%$ oil while normal DAF operations with no additives removed only $61 \%$ oil from the oily wastewater.

Fenton reagent $\left(\mathrm{Fe}^{2+} / \mathrm{H}_{2} \mathrm{O}_{2}\right)$ for phenols and $\mathrm{COD}$ destruction from Naphtha outlet section

The presence of naphtha in the wastewater of this section caused a remarkable increase in the organic matters. It was a result of the presence of phenols and other organic pollutants. The segregated wastewater collected from naphtha processing unit was treated using Fenton reaction, where the optimum operating conditions were achieved. Optimal conditions for Fenton's reagent were established and the $\mathrm{pH}$ was adjusted to 3.0. The highest percentage COD removal achieved was $88 \%$, which occurred with pre-treatment including Fenton treatment ${ }^{(14)}$.

Table 1 shows the characteristics of wastewater discharged from naphtha department. Physico-chemical analysis showed that the waste was alkaline in nature, with a $\mathrm{pH}$ - value close to 14 . Its color was yellowish-brown due to the presence of high content of phenol and other organic pollutants.

Phenolic content and COD were 160 and $8200 \mathrm{mg} / \mathrm{L}$, respectively. The total suspended solids exceed $400 \mathrm{mg} / \mathrm{L}$. On the other hand, results detected that the iron in the raw sample reached $5 \mathrm{mg} / \mathrm{L}$. The presence of this low concentration of iron may behave as Fenton like's reaction on addition of $\mathrm{H}_{2} \mathrm{O}_{2}$.

The optimal operating conditions of the Fenton's reaction were carried out according to the following variable conditions:

\section{Detection the optimum $30 \% \mathrm{H}_{2} \mathrm{O}_{2}$ dose}

Its optimum dose was detected at $0.5 \mathrm{~g} \mathrm{Fe}^{2+} / \mathrm{L}$ as a fixed dose, $\mathrm{pH}$ - value of 3.0 , reaction time of $10 \mathrm{~min}$, and stirring at $120 \mathrm{rpm}$. Two success replicates were carried out to detect the optimum $\mathrm{H}_{2} \mathrm{O}_{2}$ dose.

Results showed that, on addition of only the $0.5 \mathrm{~g} \mathrm{Fe}^{2+} / \mathrm{L}$ as a coagulant, the removal of total COD and phenol was limited to $2.0 \%$ and $12 \%$, respectively. The low efficiencies can be explained due to the removal of existing suspended solids. These results were in accordance with that obtained by Petri et al. ${ }^{(15)}$. Moreover, the addition of a series of $30 \% \mathrm{H}_{2} \mathrm{O}_{2}$ to the previous reaction, a

Egypt. J. Chem. 58, No.6 (2015) 
detectable removal in both COD and phenol was achieved as shown in Fig. 5 \& 6 . The results revealed that the optimal $\mathrm{H}_{2} \mathrm{O}_{2}$ dose for noticed COD and phenol removal was $20 \mathrm{ml} / \mathrm{L}$. Figure 5 shows that the reaction proceeds first order mode. From the cost-effective factor, there was a little bit difference between the highest dose of $40 \mathrm{ml} / \mathrm{L}$ and the chosen optimal dose.

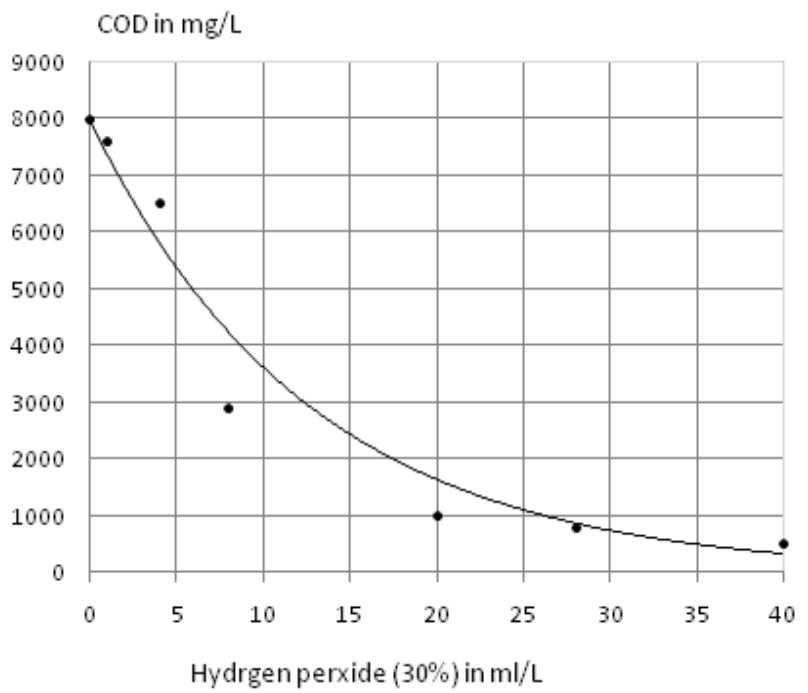

Fig.5. Optimum $\mathrm{H}_{2} \mathrm{O}_{2}$ dose versus COD.

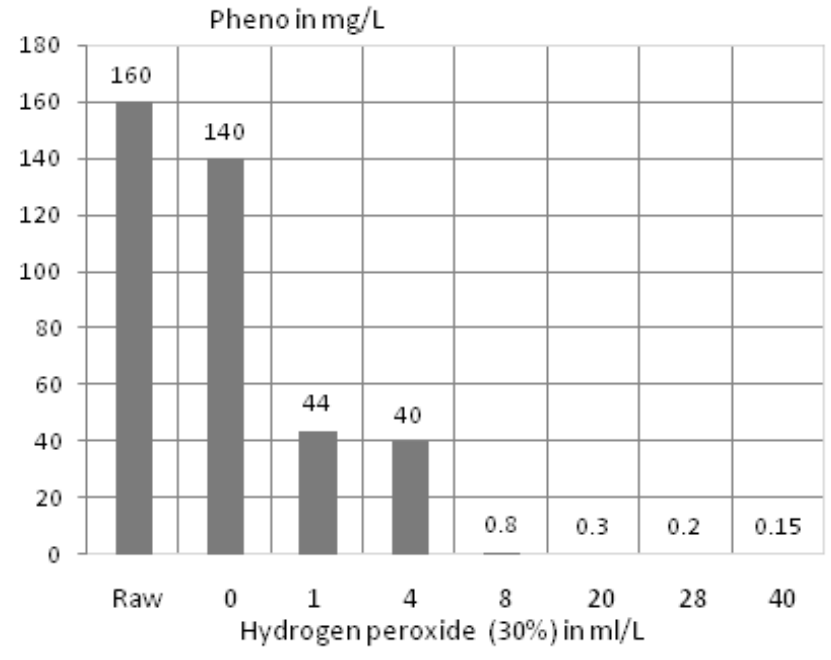

Fig.6. Optimum $\mathrm{H}_{2} \mathrm{O}_{2}$ dose versus phenol. 
Detection of the optimum $\mathrm{Fe}^{2+}$ dose

The optimum ferrous dose was detected at $20 \mathrm{ml} / \mathrm{L}$ of $30 \% \mathrm{H}_{2} \mathrm{O}_{2} / \mathrm{L}$, pH- value 3.0 , reaction time of $10 \mathrm{~min}$, and $120 \mathrm{rpm}$ using Jar Test apparatus.

Results in Fig. 7 explain the partially decomposition $39 \%$ of organic matters $\mathrm{COD}$, without adding $\mathrm{Fe}^{2+}$ dose. This explains the effect of internal presence of 5 $\mathrm{mg} / \mathrm{L}$ iron content, which behaved as Fenton like reaction. On the other side, Fig. 8 represents the calculated optimal $\mathrm{Fe}^{2+}$ dose $0.2 \mathrm{~g} / \mathrm{L}$. It was enough to decompose about $93 \%$ from phenolic compounds. The obtained results were supported by results recorded by Steiner and $\mathrm{Gec}^{(16)}$.

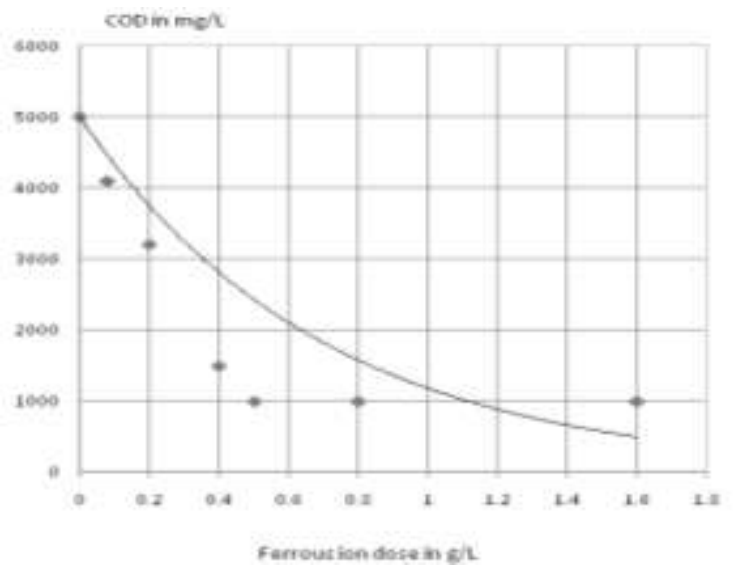

Fig.7. Optimum $\mathrm{Fe}^{2+}$ dose versus COD.

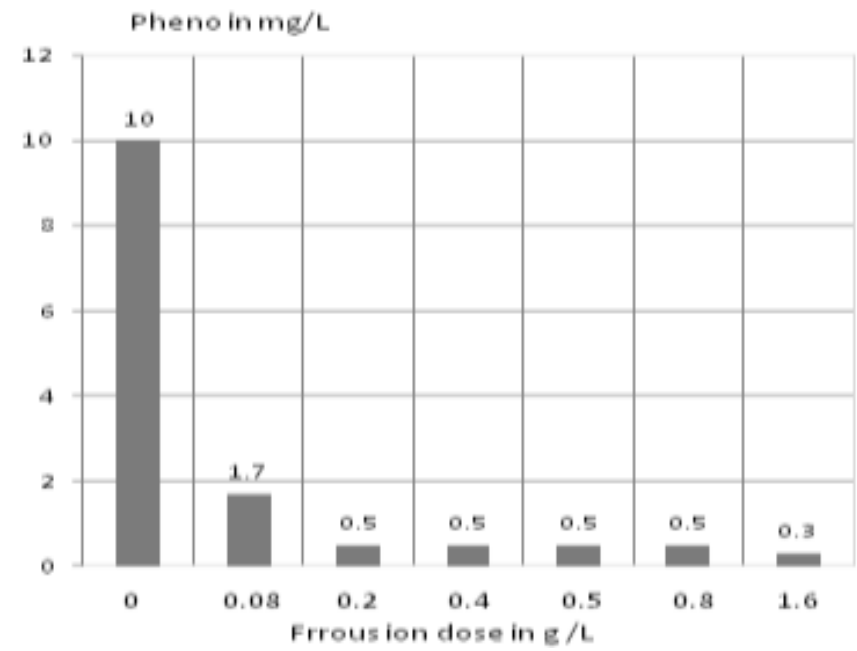

Fig. 8. Optimum $\mathrm{Fe}^{2+}$ dose versus phenol.

Egypt. J. Chem. 58, No.6 (2015) 
Detection of the optimum $\mathrm{pH}$-value

At the optimum ferrous dose $0.5 \mathrm{~g} / \mathrm{L}, 20 \mathrm{ml} / \mathrm{L}$ of $30 \% \mathrm{H}_{2} \mathrm{O}_{2} / \mathrm{L}$, reaction time of $10 \mathrm{~min}$, and $120 \mathrm{rpm}$ using Jar Test apparatus, the optimum $\mathrm{pH}$ - value was concluded from three repeatable successful runs.

Results obtained from these experiments revealed that the Fenton reaction can be obtained at the pH equal to 10.0 as illustrated in Fig. $9 \& 10$. When the $\mathrm{pH}$ value was reduced from 14.0 to 10.0 followed by addition of $\mathrm{H}_{2} \mathrm{O}_{2}$, the $\mathrm{pH}$ was consequently dropped to 3.0, which is the optimum value of Fenton's reaction. In this case, no need to reduce the initial $\mathrm{pH}$ to 3.0 , and this $\mathrm{pH}$ - value was chosen as effective cost value ${ }^{(17)}$.

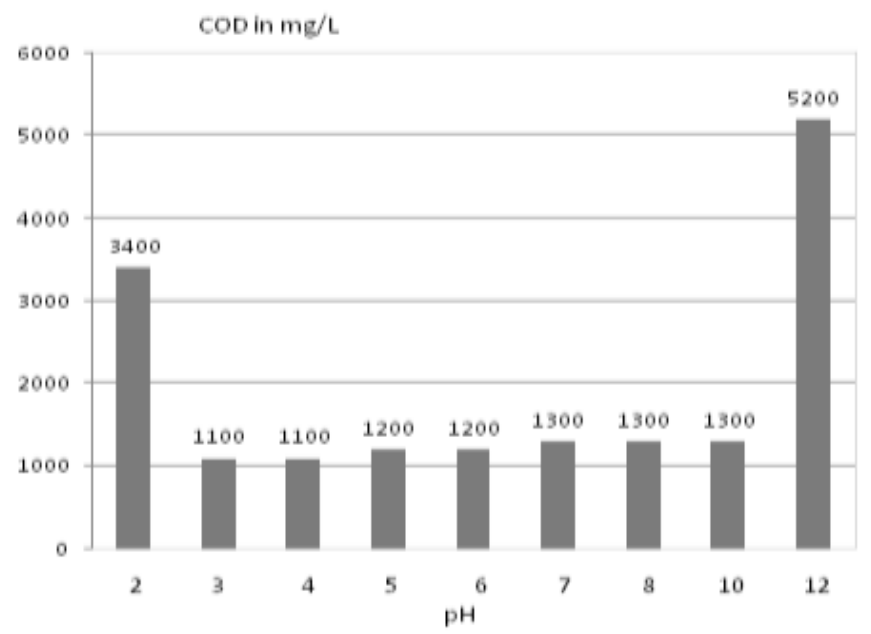

Fig. 9. Optimum pH versus COD removal.

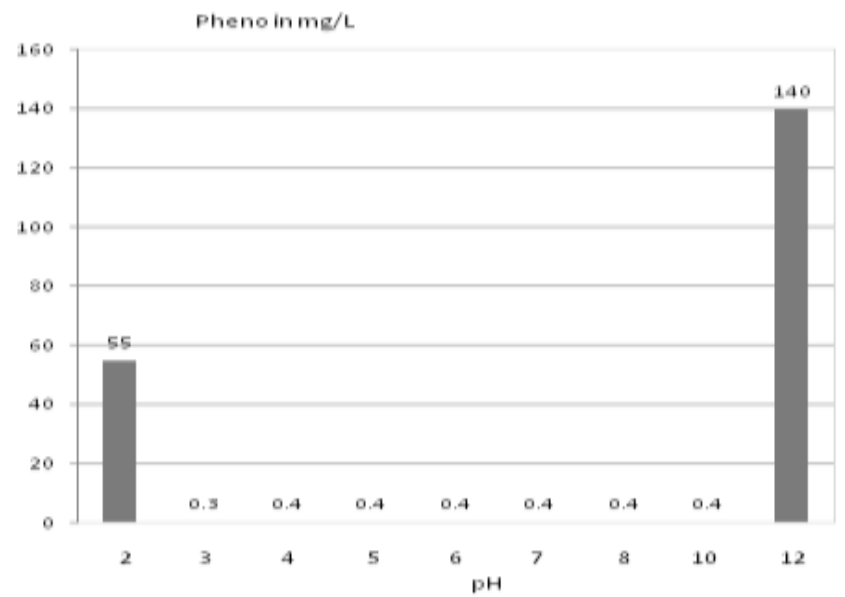

Fig.10. Optimum pH versus phenol removal.

Egypt. J. Chem. 58, No.6 (2015) 619 
Detection of the optimum reaction time

At the optimum conditions of ferrous dose $0.5 \mathrm{~g} / \mathrm{L}, 20 \mathrm{ml} / \mathrm{L}$ of $30 \% \mathrm{H}_{2} \mathrm{O}_{2} / \mathrm{L}$, $120 \mathrm{rpm}$ and $\mathrm{pH} 10.0$ using Jar Test apparatus, the optimum contact time was measured. These results were in accordance with that obtained by Szulbinski ${ }^{(17)}$.

Results conducted that the optimum reaction time to obtain the required results was 10 min as declared in Fig. 11 and 12.

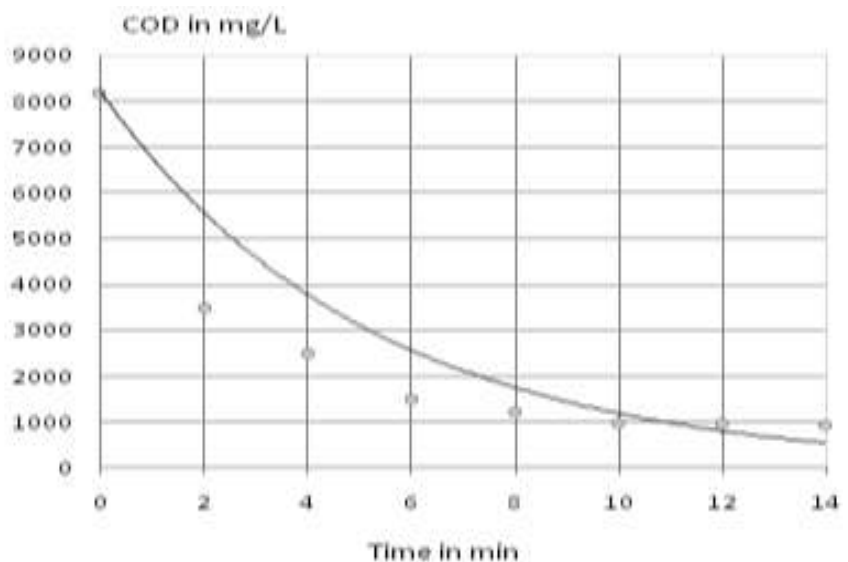

Fig. 11. Optimum time versus COD removal.

These data were in accordance with that obtained by Syllos et al. ${ }^{(3)}$, where above $90 \%$ degradations were reached in all cases after 90 min of reaction. Results were attaining $100 \%$ mineralization in the optimized concentrations of Fenton reagents, and the process integration was adequate with $100 \%$ organic load removal in $20 \mathrm{~min}$.

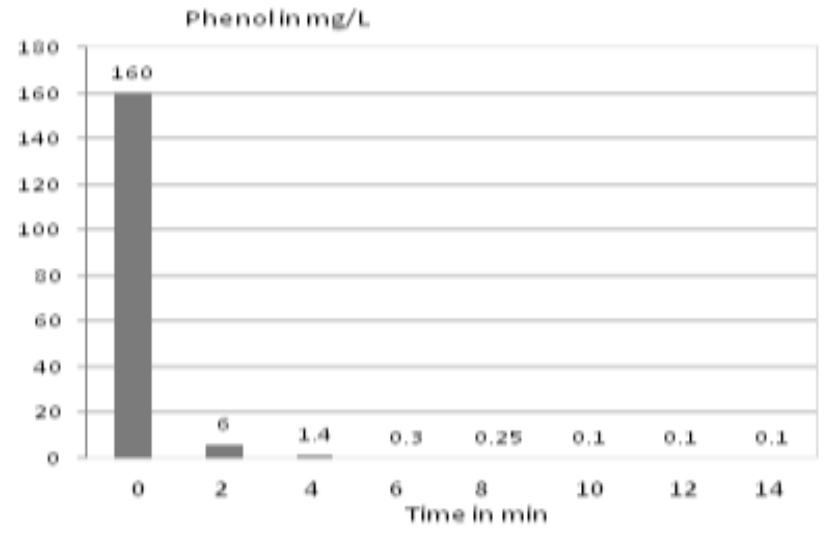

Fig.12. Optimum time versus phenol removal.

Egypt. J. Chem. 58, No.6 (2015) 
The overall schematic diagram of Fenton reaction is illustrated in Fig.13.

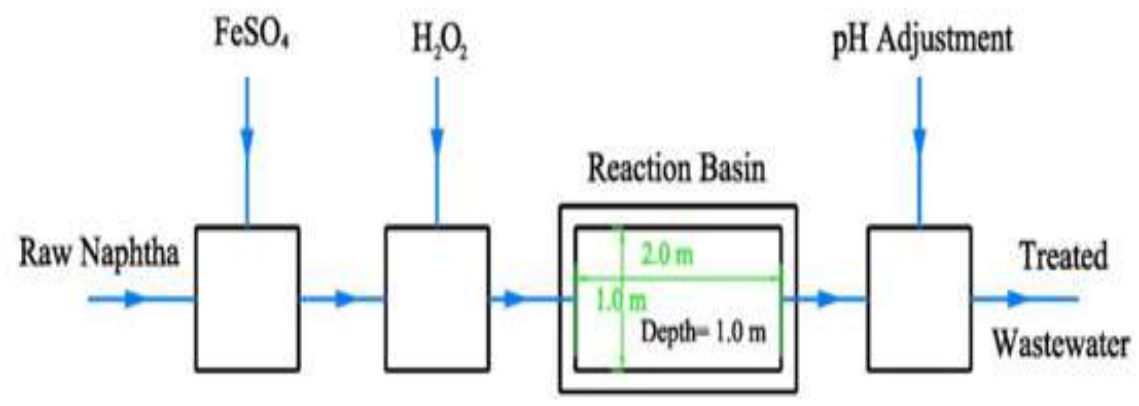

Fig. 13. Schematic diagram of Naphtha destruction using Fenton reaction.

\section{Conclusion and Recommendations}

- Two different types of real wastewater samples were collected from the petroleum refinery company under investigations, Egypt. The first was one from the API-oil separation unit outlet. DAF- procedure was carried out unit, where the unit showed an appropriate treatment method for removing of oil and grease to $98 \%$, COD to $96 \%$ and TSS to $92 \%$.

- Wastewater from the API-oil separation unit outlet (I), DAF- unit (Table 1) showed an appropriate treatment method for removing oil and grease; COD and TSS were up to $99 \%, 96 \%$ and $98 \%$, respectively.

- Wastewater collected from Naphtha department (II) subjected to Fenton processes, which effectively oxidize and remove phenolic organics more than $99.9 \%$ (the initial phenol load $=160 \mathrm{mg} / \mathrm{L} * 12.5 \mathrm{~m}^{3} / \mathrm{h} * 24 \mathrm{~h}=0.048 \mathrm{~kg} /$ day; phenol load after treatment $\left.=0.1 \mathrm{mg} / \mathrm{L} * 12.5 \mathrm{~m}^{3} / \mathrm{h} * 24 \mathrm{~h}=0.00003 \mathrm{~kg} / \mathrm{day}\right)$ and about $88 \%$ removal of COD $\left(8200 \mathrm{mg} / \mathrm{L} * 12.5 \mathrm{~m}^{3} / \mathrm{h} * 24 \mathrm{~h}=2.46 \mathrm{~kg} / \mathrm{day}\right.$, COD load after treatment $=1000 \mathrm{mg} / \mathrm{L} * 12.5 \mathrm{~m}^{3} / \mathrm{h} * 24 \mathrm{~h}=0.30 \mathrm{~kg} /$ day $)$ at optimum condition, the $\mathrm{Fe}^{2+}$ dose was $0.5 \mathrm{~g} / \mathrm{L}$, the $(30 \%) \mathrm{H}_{2} \mathrm{O}_{2}$ dose was $20 \mathrm{ml} / \mathrm{L}$, the reaction time is $10 \mathrm{~min}$ the starting $\mathrm{pH}$ value is 10 because of a cost-effective factor because the target wastewater had an original $\mathrm{pH}$ near to 14 .

From this study, it is apparent that the implementation of removal of oil from wastewater (I) and destruction of phenolic compound via advanced oxidation of wastewater (II) produces a good quality effluent that complying with the Egyptian Environmental Regularity Standards for wastewater discharge into the sea according to discharging levels. 


\section{References}

1. Durell, G., Utvik, T.R., Johnsen, S., Frost, T. and Neff, J., Oil well produced water discharges to the North Sea. Part I: Comparison of deployed mussels (Mytilusedulis), semi-permeable membrane devices, and the DREAM model predictions to estimate the dispersion of polycyclic aromatic hydrocarbons. Marine Environmental Research, 62,194-223 (2006).

2. Coates, J.D., Chakraborty, R. and McInerney, M.J., Anaerobic benzene biodegradation - a new era. Res. Microbiol. 153, 621-628 (2002).

3. Syllos, S., Osvaldo, C-F., Eduardo L., Netoa, de B. and Nascimentob, C., Integration of processes induced air flotation and photo-Fenton for treatment of residual waters contaminated with xylene. J. Hazard. Mater. 199,151-157 (2012).

4. Abdel Megid, M.H., Amer, A.A. and Elsayed, K.H., Coagulation and dissolved Air floatation for treatment of oil-water emulsion. Int. J. Eng. Sci. 3 (12),120-129(2014)

5. Tony, M.A., Purcell, P.J., Zhao, Y.Q., Tayeb, A.M. and El-Sherbiny, M.F., Photocatalytic degradation of an oil-water emulsion using the photo-Fenton treatment process: Effects and statistical optimization. J. Environ. Sci. Health Pt. A, A44. 2,179187 (2009)

6. El-Awady, M.H., Treatment of wastewater from meat manufacturing industry-case study. Int. J. Environ. Stud. 56, 345-356 (1999).

7. El-Gohary, F., Tawfik, A. and Mahmoud, U., Comparative study between chemical coagulation/ precipitation (C/P) versus coagulation/dissolved air flotation (C/DAF) for pre-treatment of personal care products (PCPs) wastewater. Desalination, 252,106-112 (2010).

8. Tchobanoglous, G., Burton, F.L. and Stensel, H.D., Wastewater Engineering: Treatment and Reuse / Metcalf \& Eddy, Inc. The McGraw-Hill Series in Water Resources and Environmental Engineering (4 ${ }^{\text {th }}$ ed.): p. XXVIII, p. ill. 1819 (2003).

9. Fenton, H.J.H., Oxidation of tartaric acid in presence of iron. J. Chem. Soc. 65, 899$911(1894)$

10. Abdelfattah, I.A.A., Treatment of Liquid Hazardous Waste and Highly-Loaded Industrial Wastewater by Photo-Fenton process including Noxiousness Assessment, Book, ISBN: 978-3-8356-3245-5, Stuttgarter Berichte zur Abfallwirtschaft, Edited by FEI, Stuttgart, Germany (2011).

11. Haber, F. and Weiss, J., The catalytic decomposition of hydrogen peroxide by iron salts. Proc. Roy. Soc. Lond. 147, 332-351 (1934).

12. El-Awady, M.H., Estefan S.F, Kamel, E.M., Abdel-Alim, I.A. and Zayed, M.F., Utility of Hydromag- $\mathrm{TiO}_{2}$ in the photocatalytic degradation of the textile's effluent and dyes. Egypt. J. Chem. 48 (3), 345- 353 (2005). 
13. APHA, AWWA, WEF Standard Methods for Examination of Water and Wastewater. $22^{\text {nd }}$ ed. Washington: American Public Health Association (APHA) ISBN 978087553-013-0 (2012).

14. Tony, M.A., Purcell P.J. and Zhao, Y., Oil refinery wastewater treatment using Physico-chemical, Fenton and Photo-Fenton oxidation processes. J. Environ. Sci. and Health, Part A: Toxic/Hazardous Substances and Environmental Engineering, 47 (3), 435-440 (2012).

15. Petri, C., Vasileia P.C.Y.M.P.M. and Fatta-Kassinos, D.C.M.N.K.D.M.D., Sequential coagulation-flocculation, solvent extraction and photo-Fenton oxidation for the valorization and treatment of olive mill effluent. Chemical Engineering Journal, 224, 82-88 (2013).

16. Steiner, N. and Gec, R., Plant experience using hydrogen peroxide for enhanced fat flotation and bod removal. Environmental Progress , 11 (4), 261-264 (1992).

17. Szulbinski, W.S., Fenton reaction of iron chelates involving polyazacyclononane. The ligand structure effect. Pol. J. Chem. 74 (1),109-124 (2000).

(Received 31/ 8/2015;

accepted 7/10/2015) 


\section{معالجة المخلفات السائلة للصناعات البترولية باستخدام طريقتي التعويم الهوائي والأكسدة الحياتلة الحيثة

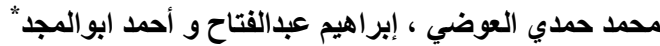

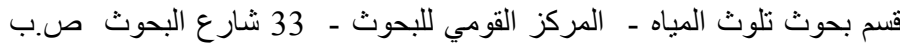

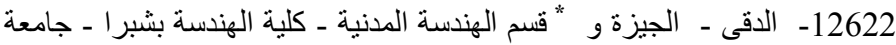

أجريت هذه الدراسة لازالة الملوثات البترولية الخطرة والزيوت من المخلفات

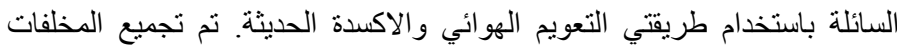

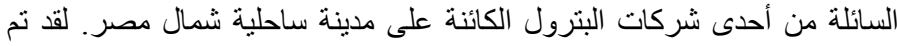

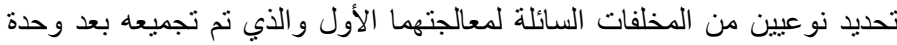

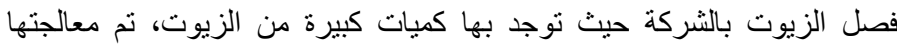

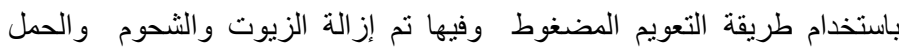

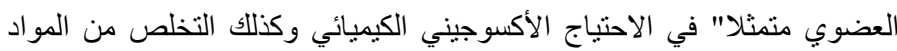

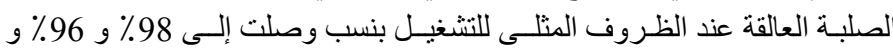

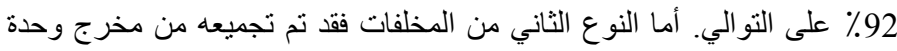

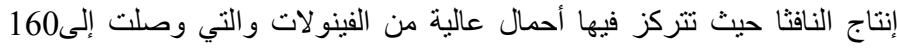

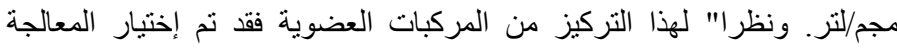

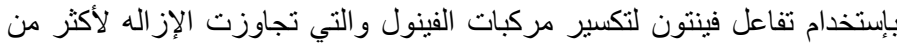

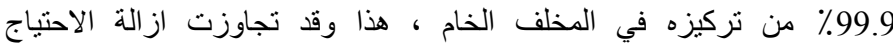

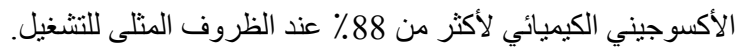

